\title{
Publisher Correction: Enhanced $\beta$-adrenergic signalling underlies an age-dependent beneficial metabolic effect of PI3K p110 $\alpha$ inactivation in adipose tissue
}

Caroline Araiz, Anqi Yan, Lucia Bettedi, Isabella Samuelson (10, Sam Virtue, Anne K. McGavigan, Christian Dani, Antonio Vidal-Puig \& Lazaros C. Foukas (i)

Correction to: Nature Communications https://doi.org/10.1038/s41467-019-09514-1, published online 4 April 2019.

The original version of this Article contained an error in Fig. 5a, in which the representative Western blot images for Akt phosphorylation in IWAT were a duplication of those for vWAT. This has been corrected in both the PDF and HTML versions of the Article.

Published online: 21 February 2020

(c) (i) Open Access This article is licensed under a Creative Commons Attribution 4.0 International License, which permits use, sharing, adaptation, distribution and C. reproduction in any medium or format, as long as you give appropriate credit to the original author(s) and the source, provide a link to the Creative Commons licence, and indicate if changes were made. The images or other third party material in this article are included in the article's Creative Commons licence, unless indicated otherwise in a credit line to the material. If material is not included in the article's Creative Commons licence and your intended use is not permitted by statutory regulation or exceeds the permitted use, you will need to obtain permission directly from the copyright holder. To view a copy of this licence, visit http://creativecommons.org/licenses/by/4.0/.

(c) The Author(s) 2020 